\title{
Role of Islamic Teachers in Combating Students' Radicalism
}

\author{
Raharjo \\ Universitas Islam Negeri Walisongo Semarang, Indonesia \\ \{raharjo@walisongo.ac.id\}
}

\begin{abstract}
Nowadays, there are many thoughts, attitudes and movements related to signs of radicalism. This phenomena have the potential actions that strengthen intolerant actions or reinforce acts of terrorism in the name of religion. This study was conducted to answer two problems: typology of radicalism, and way of combating radicalism in students. The subjects of this study were school principals, Islamic Education teachers as school spiritual leaders, students, and educational communities related to student activities. Data of this study were collected by methods of observation, questionnaires and indepth interviews. The results show that typology of radicalization consisted of three phases: transformation (students receive and listen to explanations about radicalism), internalization (they believe and conceptualize the radical values into a value system), and characterization (the values of radicalism have already entered the students). Islamic teachers had a central role in combating the radicalism in students at school. Islamic teachers were not only those who taught the Islamic teaching in the class based on the written curriculum, but also those who educated Islamic values as the hidden curriculum as well as those related to students activities outside of school.
\end{abstract}

Keywords: Combating Radicalization; Cultivating Radicalism Values; Written and Hidden Curriculum; Intra and Extra-Curricular; Role of Islamic Teachers

\section{Introduction}

Radicalism is a potential movement that may become a ticking time bomb in the form of terrorism which deeply disturb the public. Its existence is like fire in husks. The terror actions may include vandalism of public facilities or suicide bombings targeting government officials and facilities[1]. The seeds of radicalism may be in the form of mindsets and attitudes. Although radical seeds may come from various interests and / or ideologies, what is more striking one is based on religion[2], especially Islam. Muzayyin Ahyar (2015)[5] captures that the phenomenon of religious radicalism is not entirely a symptom of religious ideology, but also as a socio-political symptom. The findings of his research illustrate that radicalism is an effort to form identity using mass networks (Islam), and take advantage of political opportunities (democratic nature), mobilization and the process of framing.

Islamic teachings do not actually teach radicalism. The highest value of Islamic teachings is 'rahmatan li al-alamin'[3], which is explained in many verses found in, for example in "tafsir 
bi al-ma'tsur" i.e. explanation of Qur'anic verse by other verse(s). However, there are people who understand the verses of the Qur'an depthless, textually, and finitely. This group then explained the Qur'an freely, on behalf of "tafsir bi ar ro'yi" that is explanation of Qur'anic verse with common sense, and uses it to defend their interests, for example for politic, ideology and revenge[4][5][6].

To expand the radical movement, the radical groups promote it to and target young people[7][8], because these young people are the group that is most easily affected. They are a level of age developing mental and personalities, and in the process of looking for identity[9]. Those with a shallow understanding of religion have become easy targets for the spread of the radicalism virus. When defending their beliefs, they feel the most righteous and dare to blame and disbelieve other people who are not in their linkage, even their parents. They stay away from the mainstream groups, separate themselves from the groups, even though they are in the school environment and during the school hours[10]. They are at the forefront of treason, destroying social and government facilities, and are even ready to die for the sake of a successful jihad that will be rewarded heaven for their enjoyment.

This kind of movement must be stopped, based on at least three reasons. First, Islam requires "rahmatan li al alamin", not radicalism[11][12]. The belief of 'rahmatan li al alamin' in Islamic law must be planted in their (the actors of terror and / or the young muslims) heart adequately[13]. Second, acts of terrorism disturb the public. Innocent people become victims, and the victims' families were traumatized. Therefore, the secure and peace of the community must be maintained and created in such a way that the community feels secure and comfortable in carrying out their daily activities. This non-physical aspect makes the people's mental illness, uneasy to heal. Third, acts of terrorism often have an impact on the destruction of public facilities. Such a condition creates social imbalances, as well as their repairs will require large funds. This physical aspect is burdening the government in allocating unnecessary renovation funds. Fourth, the recklessness of terrorists is the result of brainwashing which will always cover their thought patterns, attitudes and actions on the negative side[14]. They feel most right, others (outside the group) are wrong. They are always suspicious and hate the legitimate government, including its officials. And they always tend to do damage in the name of religious truth. These young people become psychopaths, they are used by those who want to achieve glory, they live in misery in the here and will be wretched in the hereafter. Therefore, they must be saved from that negative influence. The youth are the next generation of the nation's struggle, a generation that is expected to have the responsibility and enthusiasm to build the nation. They must be equipped with good character, educated and nurtured to have an outstanding personality.

Public high school students in Ex Se-Karesidenan Surakarta (2013) [15] are very varied in facing globalization through Rohis activism in responding to the challenges of globalization itself. The results of this study indicate that Rohis activists in several schools actually support globalization as long as it is good (modernist ideology), they adhere to transformative ideas that are humanist and apply Islamic teachings kaffah, but there are also spiritual activists who oppose globalization, namely those who adhere to ideology revivalist.

Laily Fitriani (2015)[16] said that the role of pesantren is very strategic in transforming a culture of peace through peace building education. The results of his research show that Islamic boarding schools apply the principles of tasamuh (tolerant), tawasuth wal i'tidal (simple), tawazun (full of consideration) and ukhuwah (brotherhood). A complete understanding of Islam makes the pesantren community always spread human values and peace. In facing such social conditions, several questions arise, among others: First, how to stop acts of terror? In order that no further actions appear. Second, how to restore the character 
of terrorists to become good citizens and be well accepted by the community? Third, how to break the chain of spread of the radicalism virus? To be able to do this, it is necessary to know the source, route and process of its dissemination. Fourth, how to equip them with good characters and superior personalities? Fifth, where did these efforts begin to be carried out? Sixth, who should do it?

From these questions, this research is limited to two things, namely how to save young people from the influence of radicalism, and who should carry out the rescue. In the education process, there are three education centers, namely family, school, and community. This research is focused on the scope of the school, because in schools there are formal regulations that bind on all school members, especially students. Thus, teachers have an important role in stopping the spread of the virus of radicalism among their students. Operationally, this research refers to two main problems, namely: (1): How is typology of radicalism in students?

(2) What is the role of the teacher in combating radicalism in students?

This research is in the form of field qualitative one[17]. The results are presented in a descriptive narrative. The population of this study were senior high general school (SMA) and senior high vocational school (SMK) students in Central Java. The students are within 1,073 high schools, in 35 districts / cities, in 6 ex-regions in Central Java. This population is used as a field of the initial study in conducting survey mapping. Purposively, this study took 17 high school samples. Initial data collection in this study used a questionnaire method for school leaders (principal and / or vice principals of student affairs) and Islamic Education teachers. Furthermore, observations were conducted in 5 high schools to find out the real activities of students in the school environment and especially in spiritual activities. In-depth interviews were conducted with students (especially those who organize the spiritual activities), teachers (especially spiritual coaches) and a number of communities. The collected data were then analyzed using descriptive-analytical methods, that is describing the field data found with sharp and deep thinking.

\section{Literature Review}

\subsection{Radicalism}

The term 'radicalism' comes from the Latin 'radix' which means root, which implies thinking deeply about something to its roots[18]. Radical also means extreme, comprehensive, fanatical, revolutionary, ultra and fundamental[19][20]. In the Cambridge English Dictionary[21]; Radical is defined as believing or expressing the belief that there should be great or extreme social or political change.

Radicalism means doctrines or practices of adherents of radicalism or extreme understanding[22]. In the Indonesian Dictionary[23], radicalism is defined as an ideology or a sect that wants hard or drastic change. Radicalism is often interpreted differently between interest groups. In the religious sphere, radicalism is a religious movement that attempts to completely overhaul the existing social and political order by means of violence[3]. Whereas in the study of Social Sciences, Radicalism is defined as a view that wants to make fundamental changes in accordance with its interpretation of social reality or the ideology it embraces[24]. Thus, radicalism is a general symptom that can occur in a society with various social, political, ideological, cultural and religious motives, which are marked by violent, extreme and anarchist actions as a form of rejection of the symptoms at hand. Meanwhile, radicalization is a process, method, or act of radicalizing. 
The emergence of the radicalism movement, according to Yusuf al-Qardawi[25], is due to many factors, namely: (1) Religious knowledge that is partly through a doctrinal learning process. (2) Literally in understanding religious texts so that radicals only understand Islam from its skin but with minimal insight into the essence of religion. (3) Busy with secondary problems such as moving the fingers during tasyahud, lengthening the beard, and raising the pants while forgetting the primary problems. (4) Excessive in banning many things that actually burden the people. (5) Weak in historical and sociological insights so that their fatwas are often contrary to the welfare of the people, common sense, and the spirit of the times. (6) It is not uncommon to appear as a reaction to other forms of radicalism such as the radical attitude of secularists who reject religion. (7) Resistance to social, economic, and political injustice in society. In addition to these seven factors, Azyumardi Azra[26] added that the emergence of radicalism is also due to: (1) Still continuing intra and inter-religious nuanced social conflict during the reform period due to various factors are very complex. (a) Euphoria of freedom and will without caring about the other parties, resulting in symptoms of decreased tolerance. (b) Political and social fragmentation continues, especially among the political, social, military elites, which scans the grassroots and causes latent and widespread horizontal conflicts. (c) Inconsistency in law enforcement. (d) Widespread disorientation and dislocation in Indonesian society, due to difficulties in daily life. As a result, these fallen and scattered people or groups can easily take emotional action, and can even be hired to commit acts of lawlessness and violence. (2) Through the internet, in addition to using paper media, radial groups also use the virtual world to distribute books and information about jihad.

\subsection{Religious Spirit of Young People}

Youth diversity is two words which have one meaning. Adolescents recognize and find their "self" not just a physical body, but a spiritual psychological life in the form of a "person." Teenagers are critical of themselves. His thoughts, feelings, desires, ideals and other spiritual psychological life are his personal property. This appreciation of personal self-discovery is called "individuation", which is a clear dividing line between oneself and not oneself. Religion, according to Glock Stark as quoted by Ancok and Suroso[28], has five dimensions, namely: belief, religious practice, experience, religious knowledge, and consequences of commitment. The dimension of belief contains hope in which religious people hold fast to certain theological views and acknowledge the truth of these doctrines. The dimensions of religious practice include worship behavior, obedience and things that are done to show commitment to the religion they profess. The experiential dimension contains the fact that all religions contain certain expectations. The dimension of knowledge refers to the expectation that religious people have at least some knowledge of the basics of belief, rites and scriptures. The dimension of the consequences of commitment refers to the identification of the consequences of one's religious beliefs, practices, practices, and knowledge from day to day. Thus, adolescent religiousness is a psychological condition that includes beliefs, religious practices, experiences, religious knowledge, and the consequences of commitment, which exist in the adolescent's person.

Religious maturity for adolescents is important to pay attention to because: (1) Religious maturity is formed from experiences that shape the response or stimulus they receive in the form of religious concepts and principles. According to Sururin[30], religious maturity is the ability of a person to cling to the religion he believes in and is manifested in daily life with full responsibility accompanied by deep religious knowledge. (2) There is a spirit of seeking truth, faith, a sense of wholeness, and the best ways to relate to humans and the natural environment. 
(3) Religion is comprehensive, can direct and solve various problems in life, universal and tolerant and able to accept differences and mature personalities.

Students who are not yet religiously mature often have strong turmoil to carry out their worship, but are less consistent and less integrated with religious behavior, for example, sometimes the turmoil of their worship is only influenced by others. The risk is that when students are thirsty for religious knowledge, they are unwittingly entered by the narrative of radical thoughts as if the radical narrative is the correct one.

The school environment as an external factor in developing students' religious awareness is formally carried out in the teaching and learning process. Due to the limited time for formal activities in the classroom, each school develops its creativity to facilitate its students in exploring religious material through extracurricular activities, known as Rohis (Islamic Spirituality)[31]. Rohis is an Islamic missionary organization under the OSIS (Student within Scholl Organization) that accommodates Muslim students' activities[32].

According to Koesmarwanti and Nugroho Widiyantoro[33], Rohani Islam (Rohis) means an extra-curricular organization run by students to carry out da'wah activities at school. The goal is to support and help meet the success of intra-curricular coaching, to increase knowledge, skills, attitudes, and expand students' thinking, all of which can affect their learning achievement.

In several studies[31], [34]-[37], Rohis has been recognized as having a positive role in: (1) shaping students' religious attitudes in the form of ritualistic and ceremonial activities, fostering good tolerance, warding off promiscuity, drugs, and brawls; (2) forming students' religious behavior through various kinds of religious activities, the use of social media, Rohis communication books, and SMS Taujih; (3) Islamic da'wah which is packaged in Sunday morning lectures, recitation, and istighosah; and (4) religious activities such as congregational zuhur prayers, Friday prayers, istighosah, Islamic studies forums, sacrificial animal slaughter, social service, PHBI, religious tourism, Friday bulletin, and competitions.

However, various reports[10], [26] in the mass media indicate that Rohis (Rohani Islam), which is a forum for Islamic religious development for students in schools, has become a nursery for radicalism from radical religious groups that infiltrate Rohis activities in schools. Regarding various activities of Rohis activities in senior high schools (SMA), anyone, including PAI teachers, must be warned to be aware of extra-curricular religious activities managed by students as well as activities in mosques and schools. The two activities are suspected as one of the entry points for the understanding of supporters of violence infiltrated by children. Until now, the factors that cause Rohis activists to have a narrow and exclusive understanding and view of religion must be sought and mapped so that there are treatments to overcome them according to the symptoms they cause.

\section{Results and Discussion}

The data collected in this study were analyzed according to the problem formulations, namely typology of radicalism, and way of combating radicalism. This grouping is adjusted according to the development stage of the affective domain, namely receiving / attending, responding, valuing, organizing, and characterization. 


\subsection{Typology of Radicalism}

Proses of spreading radicalization consists of three steps. Three things in the formulation of the problem are transformation, internalization and characterization of radicalism values.

The transformation stage is the stage of introducing the values of radicalism to students. At this stage, students receive and listen to explanations about radicalism. This recognition is obtained through several channels. First, the family line for whose parents have entered the network either actively or passively. Second, the halaqah route which is held outside the school. Participation of students in halaqah outside of the school, because of a friend's invitation. Third, through social media channels. Even though the recipient and the informer do not know each other, their communication can last a long time through the japri (private line), resulting in a time that allows them to meet physically and intensify. Fourth, channels of social interaction, for example health assistance. As a form of gratitude and gratitude, they are invited to attend and meet in a recitation community. So that's where students begin to recognize and accept the new values.

The internalization stage is the stage of instilling radicalism values in students, such as believing, completing, and clarifying this phenomenon until the conceptualization of values becomes a value system. The first and most effective media is through the family channel including the marriage channel to increase group members in the spread of the mission. The second media is in the form of mentoring on extra-curricular spiritual activities (Islamic spirituality), especially if the tutors who provide religious values are imported from outside, for example alumni, without notification and consultation with Rohis coaches. The third media is through organizations or communities outside the school. This process is a follow-up to the previous process through family and extracurricular activities at school.

The characterization stage is the stage of strengthening the values that have entered into a person. At this stage, the values of radicalism have entered students. Such character strengthening occurs in several ways. The family line, like the initial (transformation) and middle (internalization) stages, continues up to the characterization stage. The peer group path (peers) only takes place at the transformation stage, while at the internalization stage the peer group path continues to interpersonal communication such as client-patron.

\subsection{Way of combating radicalism}

\section{a) Duties of a PAI Teacher}

Formally, the main task of Islamic Education teachers is to teach Islamic Studies subjects. In general, PAI teachers have a key role in educating Islamic students in the school. Educating Islam is not limited in the classroom, but is required to build the character of students in all life at school. Parents of students often leave responsibility for their children's education to schools, including fostering religious character, where the main responsibility rests with the Islamic Education teacher.

In the Education System Law[38], education is defined as:

Conscious and planned efforts to create an atmosphere of learning and the learning process so that students actively develop their potential to have religious spiritual strength, selfcontrol, personality, intelligence, noble character, and skills needed by themselves, society, nation and state.

And the goal of education, as stated in National System of Education, [39] is: 
To develop the potential of students to become human beings who believe in and fear God Almighty, have noble character, are healthy, knowledgeable, capable, creative, independent, and become democratic and responsible citizens.

These descriptions show that the teacher's responsibility is very heavy, not limited to teaching and learning activities in the classroom, which are designed with the written curriculum. The teacher's responsibility in educating students requires that creating an educational atmosphere in the school environment is a must. The school environment must be designed in such a way that it becomes a conducive environment in the process of fostering positive, strong and superior character as Indonesian citizens.

The duties of teachers, including PAI Teachers, as stipulated in the Law on Teachers and Lecturers[40] are:

Teachers are professional educators with the main task of educating, teaching, guiding, directing, training, assessing, and evaluating students in early childhood education through formal education, basic education, and secondary education.

In the context of teaching, the teacher's task is to arrange the teaching plan, carry out the learning process and provide evaluation to measure students' mastery of the material. In Islam, a teacher's duty is very noble, namely to lead students to have noble moral perfection, as in the treatise of Prophet Muhammad SAW. This task implies that the knowledge and skills aspects are prerequisites for the attainment of the affective aspects, namely superior character and personality. Thus, the task of PAI teachers, referring to Al-Qur'an and Hadith, is to prepare the Muslim generation to become:

1. Allah's kholifah on earth

2. mercy for all nature

3. people who are beneficial to others (humans and their natural surroundings)

4. people with superior personality

\section{b) Media and Techniques for Student Character Development}

The efforts to educate and foster student character carried out by PAI teachers, in this study, used various media, such as classrooms, places of worship as Islamic religious laboratories, extra-curricular activities and even school gates. Learning subjects in the classroom according to the formal curriculum is a mandatory task that binds teachers and students. Activities in this class are carried out in a structured manner, requiring the presence of teachers and students with strict rules. Thus, all students are required to take part in class learning. Therefore, activities in this class are a very good opportunity for Islamic Education teachers to convey the values of Islamic law and noble character.

By referring to the Islamic Religious Education (PAI) curriculum, the competencies and materials are numerous and not sufficiently conveyed in classroom learning activities. The theoretical material alone is not sufficient to be presented in the classroom, moreover practical material that requires adequate space, and moral material (for example moral development) which requires implementation in real life both inside the classroom and outside the classroom. In the schools where this research was conducted, mosques are available. This place of worship also functions as a PAI laboratory, where practical material is taught there. Dhuhr prayers in congregation and dluha prayers together are the most important worship activities in schools. The participation of students in these activities, is not only valuable to worship between human beings and their Gog, but also has a very noble social value. The implementation of the worship is obligatory for all students. However, because the existence of the mosque is not sufficient to accommodate all students at one time, the worship is carried 
out alternately. In several schools in this study, the implementation of the worship was carried out in 3 shifts, namely grade 10 , grade 11 , grade 12 . Each of these worship activities was followed by a 10-minute religious lecture, mainly by a PAI teacher or other lecturers recommended by the PAI teacher. In addition to the implementation of worship, the mosque is also used for learning Islamic subject, such as janazah depiction (practice of wearing kafan and janazah prayer). Other PAI practical subjects are carried out in other specially designed places, for example the Hajj ritual practical subject.

The teaching of PAI does not only use lecture, question and answer, and discussion methods, but also habituation. Praiseworthy behaviors should appear to be applied by students, especially outside the classroom. In the research schools that were attended by researchers, the initial habituation was carried out when students started coming to school. Near the gate, several teachers and education personnel stood to greet the students. Students enter the school environment by saying salam and shaking hands (kissing hands) with teachers and education staff. The habit of mutual respect, especially to older people, is instilled since the students come to school as a whole. Other habits such as reciting learning prayers and reading short verses of the al-Qur'an are carried out in the classroom before the first lesson begins.

To increase and improve students' competence in the field of Islamic Religion, ROHIS (Islamic spirituality) extra-curricular activities are provided. This activity was followed by students voluntarily, as were other extracurricular activities. Religious discussions, and lecture and sermon exercises are carried out there. In this research school, Rohis activities are organized by students, the position of the PAI teacher is "ing madio mangun karso" (being in the middle and giving encouragement). In this case, students can invite lecturers or tutors from outside the school, according to the topic to be discussed. Rohis is also a forum for student activities in planning other religious activities such as commemorating Islamic holidays (PHBI), slaughtering sacrificial animals and distributing them to the community, shelter and distribution of zakat fitrah, and implementation of short boarding schools in Ramadan.

The description above shows that the teacher's efforts in fostering the noble character of students are carried out in various ways, namely individually, with fellow Islamic education teachers, with school members, and with other tutors. In learning activities in the classroom, of course the teacher does it alone in delivering the PAI material, as well as fostering student character. This activity is carried out in accordance with the teaching plan that has been prepared previously.

In each of the research schools, there was 2-3 PAI teachers. In activities outside the classroom, they collaborate in carrying out activities and observations, for example praying duhur and duha together. For example, in the mosque after praying, the PAI teachers collaboratively accompany the students, where one of the PAI teachers is giving a lecturer. Collaboration of the PAI teachers was also carried out during other activities such as PHBI. As for the activities in welcoming the arrival of students in the morning, all school members (teachers and education personnel) are involved. In this activity, the whole school community is divided and scheduled, each personnel has a turn 2 times a week.

In spiritual activities (ROHIS), Islamic religious (PAI) teachers act as supervisors as well as the main resource persons. To provide a variety of tutors and religious materials and methods, the spiritual board is welcome to invite other tutors both internally (teachers at the school) and externally. The involvement of other tutors is certainly with the knowledge or recommendation of the spiritual coach (PAI Teachers), so it is known that the tutor and the material are considered safe from radicalism values. 


\section{c) Strengthening the Character of PAI Teachers}

PAI teachers, like other teachers, other than having the obligation to teach students, they also have the obligation to improve their competence in the fields of knowledge, skills and attitudes. Efforts to increase teacher competence are often called Sustainable Professional Development (PKB). These efforts can be carried out by the teacher independently or in groups. The nature of the activities can be formal as well as informal. As with the interviews with Islamic Education (PAI) teachers in this study, the Sustainable Professional Development efforts were carried out in various ways. Independently, they read religious literature, either through books or through other references, such as research results, articles, rubrics in printed and electronics mass media. They admit that they often lack information with some of their students who actively access religious information through social media. Therefore, the development of information networks is a must for every teacher, including Islamic education (PAI) teachers, who often get questions that are beyond their expectations.

Besides independently, PAI teachers are also actively participating in majlis taklim activities, both in the form of studying classical book and joint prayers (such as istighosah and mujahadah) which are held regularly (weekly or monthly). This activity is carried out jointly, even though one congregation with another congregation does not always know each other because the backgrounds of the congregation are very varied and there are no binding provisions. The participation of this majlis for Islamic Education (PAI) teachers has at least 2 functions. First, to deepen the understanding of Islamic religious knowledge, part of which is to be conveyed to students. Second, it shows that the PAI teachers are followers of the religious mainstream groups, so as not to raise suspicions of illegal activities. They even work together with the community to fight against illegal activities such as the spread of radicalism. In majlis taklim activities, some PAI teachers also admit that they often work together with their students' parents / guardians.

With the emergence of the issue of radicalism, the government, in this case, the ministry of religious affairs have a big responsibility in overcoming it. The enhancement of the character of PAI teachers in tackling the radicalism movement is carried out in various forms. Generally, PAI teachers have received an invitation from the Ministry of Religious Affairs of the Central Java regional office and attended the activities specifically for PAI teacher training in the context of overcoming issues and radicalism movements in schools. On another occasion, in several schools there was also coaching for teachers and education personnel, which was attended by officials from the regional offices of the ministry / education office and the ministry of religion. These officials serve as sources in tackling issues and the radicalism movement. Furthermore, in the PAI MGMP (Subject Teacher Conference) activities, several PAI supervisors in Central Java admitted that in addition to providing teacher competency development, they also included information on efforts to combat the spread of radicalism. The government's mission in eradicating radicalism is also emphasized through teacher organizations under socio-religious organizations (such as NU and Muhammadiyah). Thus, the effort to strengthen the character of PAI teachers is complete in the context of overcoming the issue and the radicalism movement. Although there may still be information about PAI teachers being exposed to radicalism, the number is very small. Even so, the ministry of religion, the Central Java regional office, through the PAI supervisors, continues to identify, anticipate and provide intensive guidance for PAI teachers in their working areas.

In carrying out the task of fostering students at school, $100 \%$ success certainly cannot be achieved. The existence of students at school is only about 8 hours, especially with the PAI teacher, of course less time. The majority of the influence of the issue of radicalism on 
students is obtained outside of schools, because there are no binding rules and no monitoring from the relevant authorities. Especially if the students' families have been exposed to radicalism, of course they have a mission to spread this issue and movement to their children. In this case, PAI teachers complain that they only do tasks according to their abilities in their work areas. Lack of time and energy in fostering students has become a common problem. So, what can be done next is to coordinate with other parties both internally at the school and with external parties. When school leaders provide adequate support both morally (for example, asking other teachers to help PAI teacher work programs) and materially (for example, providing facilities and funding support), PAI teachers get a breath of fresh air in carrying out their work program. But when the support from the school leaders decreases, the PAI teacher still has to realize his work program in accordance with existing abilities and conditions. Support for the struggle of PAI teachers can also be obtained from outside, especially those who have extensive networks, both offline and online (social media). At least they will get information about effective ways and / or positive support to strengthen their intense interest in carrying out their duties.

\section{Conclusion}

This study discusses two problem formulations. They are typology of radicalism and way of combating radicalism values among high school students in Central Java. Based on the discussion, the data are concluded that:

a. Process of radical doctrine cultivation consists of transformation (receive and listen), internalization (believe, complete and clarify) and characterization (strengthening). Students obtain the radical doctrine through various sources: family line (including marriage), social media and interaction outside of school (e.g., intensive meeting of holy mission, peer groups and interpersonal communication) and in school activities (e.g., part of Rohis activities).

b. Key role of PAI Teachers.

1. PAI teachers have a key role in educating Islamic students in the school. Educating Islam is not limited in the classroom, but is required to build the character of students in all life at school.

2. The Media used by PAI teachers in combating radicalism are classroom, Islamic religious laboratories (mosques, prayer rooms), extra-curricular activities (rohis) and the school gate. While the techniques used are individually, together with other PAI teachers, together with school residents (teachers and education staff); and together with other tutors or instructors.

3. Effort of PAI teacher to strengthen their character was conducted individually through various readings and references, independent-congregation through non-formal majlis taklim activities, together-formally through formal meeting conducted by ministry of religious affair and ministry of national education, and together semi-formal through the PAI Teachers Forum (MGMP-PAI) and meeting conducted by non-formal institutions (social \& / religious organizations). 


\section{References}

[1] F. S. Agiesta, "Bom Bunuh Diri di Polrestabes Medan, Ini Akar Masalah Tumbuhnya Radikalisme di RI," Merdeka.com, Nov-2019.

[2] S. Wibisono, W. R. Louis, and J. Jetten, "A Multidimensional Analysis of Religious Extremism," Front. Psychol., vol. 10, p. 2560, Nov. 2019.

[3] D. Rodin, "ISLAM DAN RADIKALISME: Telaah atas Ayat-ayat 'Kekerasan' dalam al-Qur'an," ADDIN, vol. 10, no. 1, p. 29, Feb. 2016.

[4] S. Franz Magnis-Suseno, Agama, Keterbukaan dan Demokrasi, 1st ed. Jakarta Selatan: pusat studi Agama dan demokrasi (pusAd) Yayasan paramadina, 2015.

[5] M. Ahyar, "Membaca Gerakan Islam Radikal dan Deradikalisasi Gerakan Islam," Walisongo J. Penelit. Sos. Keagamaan, vol. 23, no. 1, pp. 1-26, 2015.

[6] A. Lathifah, "From Qitāl to Difā': The Meaning and Behavior of Jihad according to Jihadists in Semarang City," Al-Ahkam, vol. 18, no. 1, p. 1, 2018.

[7] Saeno, "Bom Bunuh Diri : Begini Cara Perekrut Menjerat Anak-Anak Muda Masuk Kelompok Radikal Destruktif,” Bisnis.com, Jakarta, Nov-2019.

[8] B. Karsono, "Gerakan Islam Radikal di Sulawesi Selatan: Pola Rekrutmen dan Pola Gerakan Komite Persiapan Penegakan Syariat Islam (KPPSI) dan Laskar Jundullah,” J. Keamanan Nas., vol. IV, no. 2, pp. 231-246, 2018.

[9] C. T. Gray, "Educational psychology," Psychol. Bull., vol. 15, no. 9, pp. 301-311, 1918.

[10] M. S. Muchith, "Radikalisme Dalam Dunia Pendidikan," Addin, vol. 10, no. 1, p. 163, 2016.

[11] A. Rokhmad, "Radikalisme Islam Dan Upaya Deradikalisasi Paham Radikal," Walisongo J. Penelit. Sos. Keagamaan, vol. 20, no. 1, p. 79, 2012.

[12] I. Masduqi, "Deradikalisasi Pendidikan Islam Berbasis Khazanah Pesantren," $J$. Pendidik. Islam, vol. II, 2013.

[13] A. K. Nisa' and M. W. N. Tualeka, "Kajian Kritis Tentang Toleransi Beragama dalam Islam," Al-Hikmah, vol. 2, no. 2, 2017.

[14] R. M. Lobato, M. Moya, M. Moyano, and H. M. Trujillo, "From Oppression to Violence: The Role of Oppression, Radicalism, Identity, and Cultural Intelligence in Violent Disinhibition," Front. Psychol., vol. 9, p. 1505, Aug. 2018.

[15] F. Aidulsyah, N. Wibisono, and Y. A. Adi, "Kerohanian Islam (Rohis) dalam Jurang Globalisasi Aktivisme Rohis SMAN di Eks Se-Karesidenan Surakarta (Solo Raya) dalam Menjawab Tantangan Zaman,” J. Pemikir. Sosiol., vol. 2, no. Sosiologi, pp. 118, 2013.

[16] L. Fitriani, "Pendidikan Peace Building Di Pesantren: Sebuah Upaya Mencegah Radikalisasi," ULUL ALBAB J. Stud. Islam, vol. 16, no. 1, p. 117, 2015.

[17] N. K. Denzin and Y. S. Lincoln, Handbook of qualitative research. Thousand Oaks: Sage Publications, 1994.

[18] wikipedia.org, "Radikalisme (sejarah)," 2020. [Online]. Available: https://id.wikipedia.org/wiki/Halaman_Utama.

[19] Dictionary, "Radical." [Online]. Available: https://www.dictionary.com/browse/radical. [Accessed: 21-Oct-2020].

[20] M. Dictionary, "Radical." [Online]. Available: https://www.merriamwebster.com/dictionary/radical.

[21] the C. E. Dictionary, "Radical." .

[22] Nuhrison M.Nuh, "Faktor-Faktor Penyebab Munculnya Faham/Gerakan Islam Radikal 
di Indonesia," PUSLITBANG Depag, vol. VIII, no. 31, pp. 36-47, 2009.

[23] K. B. B. I. (KBBI) and Kamus versi online, "radikalisme." [Online]. Available: https://kbbi.web.id/radikalisme.

[24] I. Hasani and B. T. Naipospos, Wajah para "pembela Islam”: radikalisme agama dan implikasinya terhadap jaminan kebebasan beragama/berkeyakinan di Jabodetabek dan Jawa Barat. Pustaka Masyarakat Setara, 2010.

[25] Y. Qardlawi, Ash Shahwah Al Islaamiyyah Baina Al Juhuud Wa At Tatharruf. Muassasah Ar Risalah, 1996.

[26] Azyumardi Azra, "AKAR RADIKALISME KEAGAMAAN: Peran Aparat Negara, Pemimpin Agama dan Guru untuk Kerukunan Umat Beragama.," in Workshop Memperkuat Toleransi melalui Institusi Sekolah, 2011, pp. 14-15.

[27] A. Rubaidi, Radikalisme Islam, Nahdlatul Ulama \& masa depan moderatisme Islam di Indonesia. Yogyakarta: Logung Pustaka, 2008.

[28] D. Ancok and F. N. Suroso, Psikologi Islami : solusi Islam atas problem-problem psikologi. Yogyakarta: Pustaka Pelajar, 2000.

[29] Raharjo, Pengantar Ilmu Jiwa Agama. Semarang: Pustaka Rizki Putra, 2012.

[30] Sururin, Ilmu jiwa agama. Jakarta: RajaGrafindo Persada, 2004.

[31] Ensiklopedia bebas Wikipedia bahasa Indonesia, "Rohani Islam," Wikipedia bahasa Indonesia, ensiklopedia bebas. 2020.

[32] “Apa Itu Rohani Islam (Rohis)?," renesia.com, 2020. [Online]. Available: https://www.renesia.com/apa-itu-pengertian-rohis/.

[33] Koesmarwanti and N. Widiyantoro, Dakwah sekolah di era baru, Cet. 1. Solo: Era Intermedia, 2002.

[34] A. Wahab, "Peran Solidaritas Kerohanian Islam (SKI) SMAN 1 Salatiga dalam Pembentukan Sikap dan Perilaku Keagamaan Peserta Didik," in Peran Rohis di Sekolah dan Pelaksanaan Kurikulum 2013 di Madrasah, 2015.

[35] U. Muzayanah, "Peran Rohis dalam Pembentukan prilaku Keagamaan Siswa di Sekolah (Studi atas Rohis At-Tarbiyah SMAN 1 Ungaran)," in Peran Rohis di Sekolah dan Pelaksanaan Kurikulum 2013 di Madrasah, 2015.

[36] Yustiani, "Peran Rohis Majlis Taklim dalam Pembentukan Perilaku Keagamaan Peserta Didik SMAN 1 Kendal," in Peran Rohis di Sekolah dan Pelaksanaan Kurikulum 2013 di Madrasah, 2015.

[37] A. Wibowo, "Peran Rohis dalam Pembentukan Sikap Keagamaan Peserta Didik (Studi atas Peran Kerohanian Islam Nurul Ilmi SMAN 3 Pekalongan)," in Peran Rohis di Sekolah dan Pelaksanaan Kurikulum 2013 di Madrasah, 2015.

[38] P. RI, "Undang-Undang No.20/2003 tentang Sistem Pendidikan Nasional," 2003.

[39] P. RI, "PP 19/2005 tentang SNP," 2005.

[40] P. RI, "Undang-Undang No.14/2005 tentang Guru dan Dosen,” 2005. 